\title{
A Tale of Two Settlements: Danish Immigrants on the American Prairie and the Argentine Pampa, 1860-1930
}

\author{
MARÍA BJERG
}

IN ARGENTINA in 1997, members of the Danish Lutheran congregation of Tandil gathered in the church their ancestors had built in the 1870s to meet a descendant of Hans Fugl, the first Danish pioneer in the region. The pioneer's great-grandson, who had traveled from Denmark to learn about the place where his great-grandfather had lived between 1848 and 1875, was astonished by the welcome he received. Here, in a remote corner of South America, an active Danish-Argentine community comprising fourth- and fifth-generation Danes still spoke Danish with the old accent of Mön, the island Hans Fugl had left more than 150 years ago. In fact, the congregation's pastor, a Dane from Copenhagen, communicated with her parishioners exclusively in Danish.

Two years earlier in Iowa, the Cedar Valley Dane Club organized a similar gathering at the Bethlehem Lutheran Church in Cedar Falls. That gathering, too, was marked by abundant signs of ethnicity: the president of the club had a T-shirt displaying the first verse of the Danish national anthem; the tables were decorated with the colors of the Danish flag; the dinner included Danish dishes following traditional ancestral recipes. Yet few of the people present could speak the language of their Danish ancestors.

1. The focus for this paper emerges out of a comparison of two different personal research experiences with Danish immigrants in the rural areas of the THE ANNALS OF IOWA 59 (Winter 2000). (C) The State Historical Society of Iowa, 2000. 


\section{THE ANNALS OF IOWA}

What accounts for the differences in Danish immigrants' adaptation to Argentine and American society? As historians of American ethnicity have shifted away from an earlier emphasis on assimilation, they have begun to focus on chain migration and settlement in ethnic enclaves to explain the persistence of ethnic traditions. The following comparative study of the reproduction, transformation, and continuity of Danish culture in the rural worlds of the state of Iowa and the province of Buenos Aires suggests that the explanation may be more complicated. Although various factors contributed to the differences in the process of adjustment, the influence of churches and schools (or religion and education) on the definition, demarcation, and perpetuation of ethnic boundaries in both settlements was especially important. In particular, the weakness of Argentine schools prompted Danish immigrants to establish and continue their own schools, which perpetuated Danish language and cultural traditions. On the other hand, the strength of American public schools where English was used meant that immigrants' children brought English into the homes and eventually forced even Danish churches to adapt.

THE EARLY HISTORIES of the Danish immigrant communities in the state of Iowa and the province of Buenos Aires have much in common. Danish immigrants began to arrive in Iowa in the 1860s, settling in Cedar Falls and in Clinton County and turning the villages of Fredsville in Grundy County, Elk Horn in Shelby County, and Kimballton in Audubon County into pre-

province of Buenos Aires, and in the agricultural Danish settlements in the state of Iowa. Prior to my arrival in Iowa in 1995 to conduct research, I had conducted community studies to analyze Danish immigrants' adjustment to Argentine society. See María Bjerg, "Dinamarca bajo la Cruz del sur: Los asentamientos daneses del sudeste de la provincia de Buenos Aires, 1848-1930" (Ph.D. diss., Universidad de Buenos Aires, 1994). In Iowa I sought a similar ethnic enclave with a high degree of ethnic consciousness and cultural preservation. Instead, while I found a replica of the Little Mermaid in Kimballton and a Danish museum in Elk Horn, testifying to the connection of both towns with a Danish past, I also found second- and third-generation DanishAmericans who were unable to speak Danish. When I began to look in historical records, I found that Iowa's "Little Denmarks," which resembled in many ways the Danish settlements of the Argentine pampa, had emerged in distinctive ways from the prairies of late nineteenth- and early twentieth-century Iowa. 


\section{MAP 1}

DANISH SETTLEMENTS IN

THE STATE OF IOWA

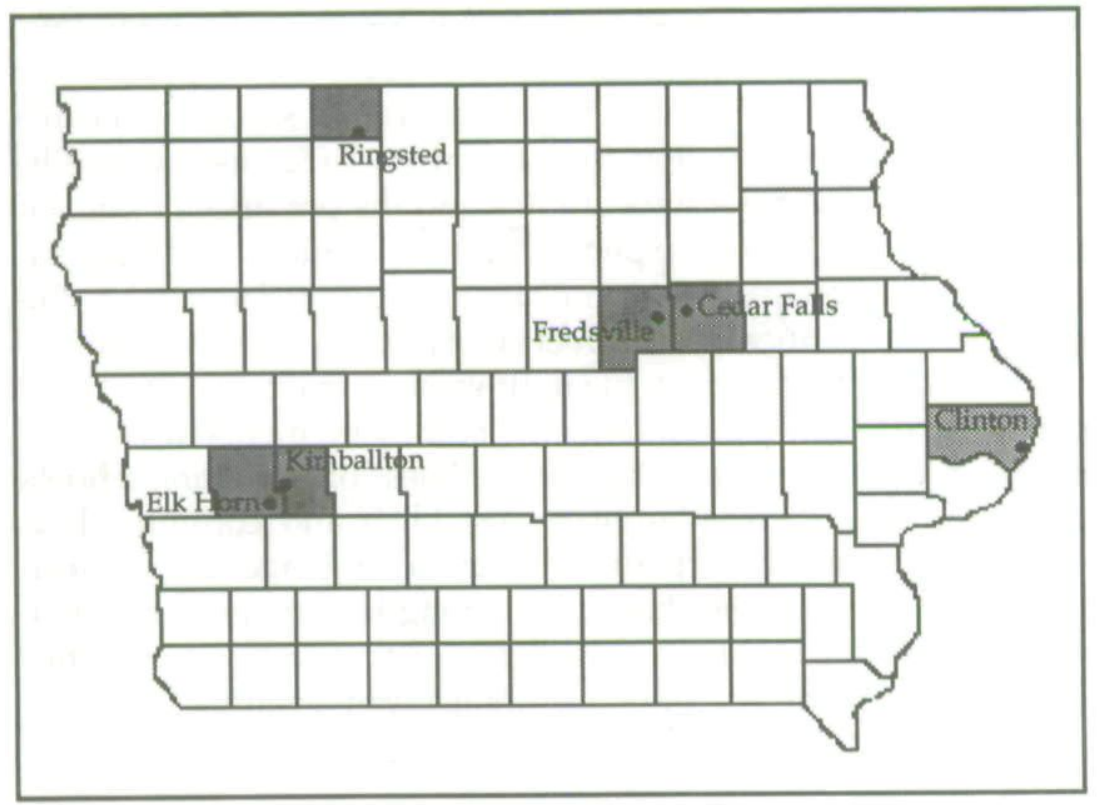

dominantly Danish settlements (see map). In the late 1880 s Danish farmers began to be attracted to Emmet County in the area that later would be called Denmark Township. Fredsville and Elk Horn were populated mostly by Danish immigrants from Slesvig in southern Jutland, while Denmark Township and Kimballton received large groups of immigrants from the areas around Limfjord in the north of the peninsula. Most of Iowa's Danish population settled in clusters. In the 1880 s and 1890 s those clusters attracted additional immigrants from the Danish islands of Mön, Aero, and Lolland-Falster. The later immigrants, who had arrived in America in the 1850s and 1860s, had settled initially in Wisconsin and Illinois but later followed the promise of prosperity to the prairies of Iowa. ${ }^{2}$

2. Thomas Peter Christensen, A History of the Danes in Iowa (Solvang, CA, 1952); Jette Mackintosh, Danskere i Midtvesten: Elk Horn-Kimballton bosaetelsen, 18701925 (Copenhagen, 1993). 
MAP 2

DANISH SETTLEMENTS IN

THE PROVINCE OF BUENOS AIRES

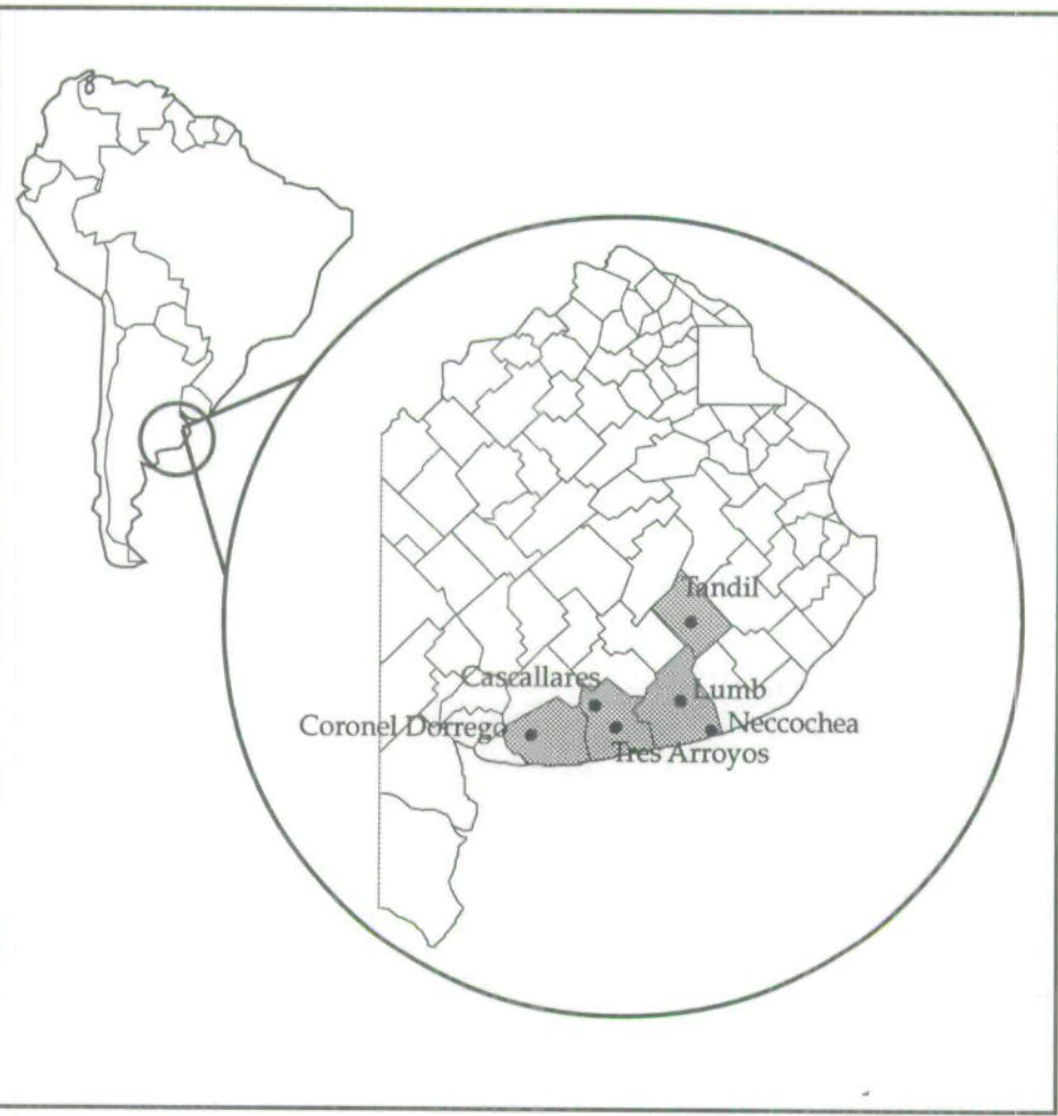

Argentina's first group of Danish immigrants arrived in Tandil in the summer of 1860 from the parish of Magleby on the island of Mön in eastern Denmark. Until the late 1880s, Tandil was the sole Danish settlement in the province of Buenos Aires, but after the southern partidos of Tres Arroyos, Necochea, and Coronel Dorrego were incorporated, ${ }^{3}$ Danish immigrants began a slow but steady march into that area. Most of them came from the Limfjord parishes in the north of Jutland or the districts of

3. Partidos are administrative divisions comparable to American counties. 
Aarhus and Randers in the central area of the peninsula. ${ }^{4}$ By 1914, 3,872 Danes resided in Argentina, with 58 percent concentrated in the rural areas of the southern province of Buenos Aires, 19 percent in the capital city, and the rest thinly distributed over the country. ${ }^{5}$ In the twentieth century, most Danes and their descendants settled in the partidos of Tandil, Tres Arroyos, Necochea, and Coronel Dorrego, the agricultural areas in the southern part of the province of Buenos Aires.

Danish immigrants in the United States were more widely distributed across the country than Danes in Argentina. Although 45 percent of the Danish immigrants in 1910 were concentrated in five midwestern states-Iowa, Illinois, Wisconsin, Minnesota, and Nebraska-no state counted more than 10 percent of America's Danish-born population. Iowa, with 18,000 Danes in 1910, was the most popular destination for Danish immigrants. ${ }^{6}$ In spite of the dispersion of the Danish population, Danes in Iowa, like those in Argentina, lived in ethnic communities with high concentrations of Danish and Danish-American population. In late nineteenth-century Iowa, Danish clusters in Elk Horn, Kimballton, Ringsted, and Fredsville organized their social, economic, cultural, and religious life along ethnic lines. As in Argentina, the hub of the Danish settlements of Iowa in the nineteenth century was the ethnic church, which regulated the Danish farmers' religious, social, and cultural life. Those farmers settled in ethnic clusters, spoke Danish on a daily basis, sent their children to a Danish Bible school, and on Sundays attended religious services conducted in Danish by pastors who had been ordained in Denmark. By the late 1910s, however, the

4. Register over udvandrere indirekte, 1869-1935, Landsarkiv for Sjealland, Copenhagen.

5. Tercer Censo Nacional de Población (Buenos Aires, 1914). Although Danish immigrants began to arrive in Argentina in the 1860s, the number was modest during the second half of the nineteenth century. In the first and second national censuses (1869 and 1895) Danes were included in the category "other Europeans." From the manuscript returns of both censuses, we can estimate that about 100 Danes resided in Tandil in 1869; in 1895, there were 1,417 Danes in the whole country, 46 percent of whom resided in the southern partidos of the province of Buenos Aires.

6. U.S. Bureau of the Census, Thirteenth Census of the United States, vol. 2, Population (Washington, DC, 1913), 618. About 14,200 Danes lived in California in 1910. 
Danish language was used only once or twice per month in Iowa churches, and it was dropped entirely from the services between the late 1930s and mid-1940s. Moreover, during these decades, the Danish churches lost their ethnic identification by becoming American Lutheran churches. ${ }^{7}$

In the old churches of the Danish-Argentine ethnic community, on the other hand, the immigrants' descendants still keep their beliefs and cultural traditions. Twice monthly, the Danish pastor who is in charge of the church of Necochea conducts a Lutheran religious service in Danish. The rest of the month, while the Danish pastor visits other congregations in the area, the service is conducted in Spanish by Danish-Argentine pastors ordained in Denmark. On the Argentine pampa (prairie), many Danes of the second and third generations still speak fluently the language of their ancestors and try to keep it alive. Several times per year, the four Danish Lutheran congregations organize religious and cultural celebrations for the DanishArgentines from the southern parts of the province of Buenos Aires. The gatherings are marked by Danish folk dances, foods, and songs.

Important changes that occurred after World War I affected the ethnic trajectories of the Danish settlements of Iowa and Buenos Aires. After growing gradually over the years 18801915, the pace of Danish migration to the United States began to decrease after World War I. In the 1920s U.S. immigration quota laws severely limited the flow of Danish immigrants to the American shores. In 1921 the United States set the Danish quota for immigrants at 5,694 per year. The number was further reduced in 1924 to 2,789 and in 1927 to $1,181 .^{8}$ This partial closing of "the golden door" stimulated an increase in emigration from Denmark to other destinations such as Argentina. ${ }^{9}$ While Danish immigration to Iowa decreased in the 1920s, new immigrants

7. Paul Nyholm, The Americanization of the Danish Lutheran Churches in America (Copenhagen and Minneapolis, 1963).

8. Erik P. Olsen, "Emigration from Denmark to Canada in the 1920s," in Henning Bender et al., Danish Emigration to Canada (Aalborg, 1991), 125-45.

9. Danish emigration to Canada and Brazil also increased in the $1920 \mathrm{~s}$. Olsen, "Emigration from Denmark to Canada"; María Bjerg, "Dinamarca bajo la Cruz del Sur," chap. 3. 
continued to arrive in the province of Buenos Aires. More than half of Argentina's Danish immigrants arrived in the 1910s and 1920 s, following a boom in wheat production at the beginning of the century. ${ }^{10}$ Lured by the prosperity of the wheat boom, Danes foresaw a promising future for their community in the countryside. In Tres Arroyos, Necochea, and Coronel Dorrego, Danes kept investing most of their profits to purchase or lease land to enlarge their farms and ensure the persistence of their descendants in the rural pampa.

Although the Danish settlements in Iowa and Buenos Aires began to diverge in the 1920s, their earlier histories have much in common. The church was the axis of religious, cultural, and social life in both settings. Charged with the responsibility for upholding values and preserving continuity, the church served as a centripetal force by promoting the establishment of a wide array of institutions, such as the Danish and Bible school, the forsamlingshus or community meeting house, the Folk high school, the mutual aid society, and the Danish library, which offset the influence of the institutional structures of the host society.

Similarities also marked the domestic and occupational domains. Courtship and marriage, for example, occurred mostly within the confines of the ethnic community. Although Danes in Argentina were more inclined than their Iowa counterparts to arrange weddings within their ethnic boundaries, both groups maintained rates of endogamy above 70 percent throughout the period $1885-1920 .^{11}$

Farming was the main productive activity of most families in both regions. Their practices did differ significantly, however. Iowa Danes partially reproduced the agricultural traditions of

10. República Argentina, Segundo Censo Nacional de Población (Buenos Aires, 1895); Tercer Censo Nacional de Población (Buenos Aires, 1914); Consulado Danés de Buenos Aires, Informe sobre Inmigración Danesa a la República Argentina (Buenos Aires, 1924); Departamento General de Inmigración de la República Argentina, Memorias Anuales, 1881-1925; Imre Ferenczi and Walter Francis Willcox, eds., International Migration, 2 vols. (New York, 1931), 2:345-68.

11. Registro Civil, Provincia de Buenos Aires, Actas de Matrimonio Civil, 18881922, Necochea and Tres Arroyos; State of Iowa, Marriage Records, 1884-1925, Grundy and Emmet Counties, vols. 8-9, 10-12, Hyde Park Family History Center, Church of Jesus Christ of Latter-day Saints, Salt Lake City, Utah. 
the Old World, such as dairy farming on owner-operated small farms. ${ }^{12}$ Danes in Buenos Aires, on the other hand, adapted readily to the "wheat fever" of the pampa by planting large acreages of wheat on rented land.

\section{AMONG THE MOST SIGNIFICANT DIFFERENCES between} the Danish settlements in Iowa and Buenos Aires, however, was the way the ethnic map and the spatial organization of the settlements differed. Until the 1920s both communities displayed a high concentration of rural population. ${ }^{13}$ In contrast to the ethnically integrated spatial arrangements of the Danes in the pampa, however, Iowa census records and plat maps reveal a pattern of Danish clustering in which almost every neighbor was Danish or Danish-American. ${ }^{14}$ In Denmark Township in Emmet County in the 1910s, for example, a Danish farmer could sell his milk at the Danish Creamery Company, purchase hardware at Petersen's Hardware Store, help his Danish neighbors harvest their corn or put up their homes and barns, and interact only occasionally with Germans or Norwegians settled in the area. ${ }^{15}$

12. Jette Mackintosh, "Ethnic Patterns in Danish Immigrant Agriculture: A Study of Audubon and Shelby Counties, Iowa," Agricultural History 64 (1990), 59-77.

13. The area around the towns of Elk Horn and Kimballton in southwestern Iowa formed the core of the largest Danish concentration in the United States. By the beginning of the century, at least 80 percent of the population in Clay and Sharon Townships was Danish or Danish-American. By 1910, 80 percent of the population in Denmark Township and Ringsted was ethnic Dane. In Fairfield Township in Grundy County the concentration of Danish or DanishAmerican population increased from 25 percent in 1900 to almost 60 per cent in 1910. In the province of Buenos Aires the highest concentrations of Danish and Danish-Argentine population were found in the ejidos of La Dulce and Lumb in the partido of Necochea, and in Copetonas and Cascallares in the partido of Tres Arroyos. By the 1920s about 45 percent of the population in Lumb and Copetonas was ethnic Dane, while in La Dulce and Cascallares 35 percent of the rural population was Danish or Danish-Argentine.

14. Anderson Publishing Co., Maps of Fairfield Township (Des Moines, 1898 and 1911); Iowa Publishing Co., Map of Denmark Township (Des Moines, 1911); George Glenn Boysen, Harvesting Our Boysen Heritage from Fjelstrup to Fredsville (Des Moines, 1993).

15. Manuscript U.S. Census, 1910; St. Ansgar's Danish Lutheran Congregation, Ringsted, 1899-1974: A History of Our Heritage (Ringsted, 1974); Elin Koch, interview by author, Cedar Falls, April and September 1995. 
The farms of Tandil, Tres Arroyos, Necochea, or Coronel Dorrego, too, often resembled "Little Denmarks," with owners (or tenants) and hired hands speaking Danish, women preparing meals in the Old Country fashion, and children receiving a Danish education. Beyond the fences of the farm, however, neighbors would be Spaniards from León, Basques from Guipúzcoa, Italians from Basilicata, or native Argentines. In most cases, tenant farmers and rural laborers on the large estancias (land estates) of the pampa interacted daily with other European or native farmers. In the 1920s Teodoro Frolund, a Danish farmer in La Dulce (in the partido of Necochea) rented a farm in Campo Deferrari, a 9,000-acre estancia farmed by twelve tenants. Four of the estate's households were Danish; the rest were Italian, Basque, Swiss, Syrian, and Argentine. Frolund's farm was surrounded by those of four neighbors: Ricardo Laursen, a Dane from Copenhagen; German Woldfradt, an Argentine from Tres Arroyos; Valentín Haefeli and his two brothers, who had migrated from Switzerland in the 1880s; and Luis Gogeascoechea, a Basque from Vizcaya. These four linderos (rural neighbors) exchanged work year-round but mostly during the hectic harvest season. They were part of the same threshing crew, borrowed each other's equipment, animals, and labor for transporting grain, and cooperated in stacking straw. These neighbors also helped each other out during times of illness, death, and childbirth. Valentín Haefeli, for example, often drove his 1920 model Rugby car to the village of La Dulce to fetch the doctor for his linderos of Campo Deferrari. ${ }^{16}$

The residential patterns within the ethnically integrated estates of the pampa probably influenced the ethnic orientation of the Danish farmers' daily lives. In the occupational domain, Danes easily crossed the blurred ethnic boundaries. In their social and religious relationships, however, ethnic boundaries were clearly defined. Regardless of the intensity of economic relations between Danish farmers and their neighbors, the Danish community excluded non-Danes from its cultural and social life. When the harvest was done, for example, Danish

16. Ministerio de Agricultura de la Provincia de Buenos Aires, Registro de Estancias y Chacras de nuestra Tierra: Partido de Necochea (Buenos Aires, 1929); Ricardo Albeck, interview by author, La Dulce, Necochea, November 1988. 
farmers in La Dulce held a Sommerfest at Peder Mikkelsen's farm, "La Magnolia." Although large numbers of Danes from within and beyond the ejido of La Dulce gathered for the celebration, non-Danish neighbors were never invited to participate. ${ }^{17}$

It seems a paradox that in the ethnically integrated world of the estancias, where Danes had intense daily relationships with their neighbors regardless of their ethnic origin, cultural continuity has been much more profound and lasting than in the ethnic enclaves of Iowa, where the community had less contact with the outside world and with people of different ethnic origins. In Iowa, community boundaries seem to have been demarcated by the sound of the church bells that regulated the rhythm of life and death, as well as by the intensity of community social control. Harlan Boysen, the son of a Danish farmer from Fredsville, cannot recall anyone in the village who was not a Dane. During his childhood in the late 1920s, Boysen remembers, Fredsville was a close-knit community where, for example, everybody knew who was ill. When Boysen helped his father and older brothers out in the fields and the church bells started to ring, the whole team would stop to count the tolls. Boysen and the members of the team figured out who had died and knew that the next day the whole village would meet at the cemetery. ${ }^{18}$

In the province of Buenos Aires, too, the church was the hub of community life, but only from a symbolic standpoint. In Iowa, most communities had a church in their center. In the pampa, on the other hand, the Danish churches were located not in the geographical center of the rural settlements but many kilometers away, in the towns of Tandil or Necochea. On infrequent occasions during the year, Danes would visit the urban church. Once a month, the pastors rode on horseback (or later drove their cars) long distances to visit the Danish farms and conduct religious services. At those times, Danish neighbors would congregate, reaffirm their Lutheran faith, and recreate their sense of ethnic identity based not only on the reconstitution of their religious beliefs, but more importantly on the preservation of the

17. Edna Mikkelsen, interview by author, La Dulce, Necochea, April 1990. Ejidos are administrative divisions of the province of Buenos Aires comparable to townships.

18. Harlan Boysen, interview by author, Cedar Falls, Iowa, September 1995. 
Danish language and the sociability among compatriots who shared social and cultural codes.

Among Danes in the province of Buenos Aires, ethnicity seems to have been more a matter of ascription and self-identity than of geographical and social isolation. Therefore, as Frederik Barth has argued, the critical factors in sustaining cultural diversity might be sought in the social boundaries that defined the community and ordered external and internal relationships. Those relationships might be described by examining the role of kinship ties, social networks, social differentiation, and "institutional completeness" - in the way Raymond Breton understands that concept-in fostering cultural continuity. ${ }^{19}$

CHURCHES AND SCHOOLS played key roles in defining ethnic boundaries within the Danish communities and between them and their host societies in Argentina and the United States. Their different roles in each region help to explain the different ways each community adapted to its surroundings.

Throughout the 1870s and 1880s the Danish Lutheran congregations of Iowa organized ethnic schools to educate DanishAmerican children in both Danish and English. The curriculum emphasized the history, geography, and religious doctrine of Denmark in the hope that these ethnic schools would help to prepare children for the duties of American citizenship without threatening the persistence of Danish beliefs and symbols.

To accomplish their goal, Iowa's Danish communities created hverdagsskoler, or primary schools, in the settlements of Clinton, Elk Horn, Kimballton, and Cedar Falls in the 1870s and $1880 \mathrm{~s}^{20}$ Most of the initiatives came from the churches, and the most influential advocates for Danish schools were pastors, who re-

19. Frederik Barth, ed., Ethnic Groups and Boundaries: The Social Organization of Cultural Difference (Oslo, 1969), 9-20; Raymond Breton, "Institutional Completeness of Ethnic Communities and the Personal Relations of Immigrants," American Journal of Sociology 70 (1964), 193-205.

20. In the early 1890s, there were six Danish schools in Iowa: three in Elk Horn, two in Kimballton, one in Clinton, and one in Cedar Falls. Kimballton Centennial, 1883-1983 (Kimballton, 1983); Elk Horn Lutheran Church, Elk Horn, Iowa, 18751975 (Elk Horn, 1975); Thomas Peter Christensen, Dansk-Amerikansk Historie (Cedar Falls, 1927). 


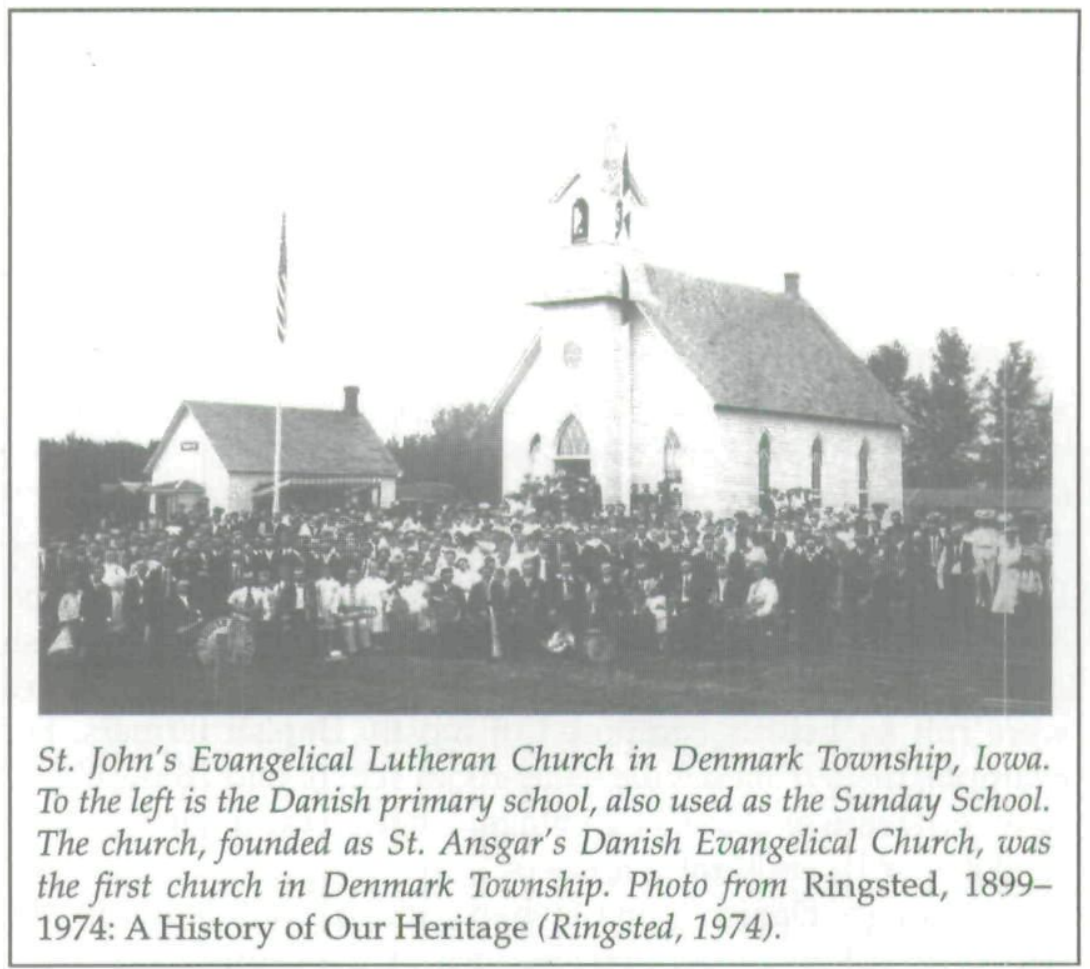

garded the education offered by America's rural schools as primitive and ineffective. According to the Danish pastors, the ineffectiveness of rural public schools was due to the poor instruction of the teachers. In addition, the ministers charged that many school board members' intellectual skills and command of English were not sufficient to assume the responsibility for managing schools. The pastors often used their pulpits to try to convince their parishioners of the importance of sending their children to Danish primary schools. Pastor M. C. Jensen, for example, told the following anecdote at the Elk Horn church:

Once I had a first-hand picture of the management of the school given by a farmer whom I was visiting and was the president of the school board: "Jo, ser De, jeg var jo bleven school director og skulde hire a teacher for next term. Jeg put saa an announcement $i$ the paper, og sa kom han ridende herind i yarden, ham Gooding inde fraa town, ... og sagde, at han var teacher og sögte Pladsen. Du er den förste der har vaeret her, sagde jeg; du skal have den. So 
tog han fat fra termens Begyndelse; og jeg tror nok, han getter along all right." ${ }^{21}$

Despite the efforts of the Danish Lutheran pastors, parents who knew the practical problems of giving children an education resisted. The number of students attending the Danish schools was always low because most midwestern Danes preferred to send their children to American schools and find more intermediate forms for religious instruction, such as Sunday and vacation schools. By the early 1890 s, the number of DanishAmerican children attending public schools had increased, while the enrollment at ethnic schools was declining rapidly. ${ }^{22}$

By the 1890 s in the Iowa townships heavily populated by Danes, many public schools dotted the countryside; a schoolhouse was within easy walking distance from every Danish dwelling. Generally, the schools in the Danish communities were run by boards composed of mostly Danish farmers. For example, in 1897 Fredsville's one-room school had 28 pupils, 20 of whom were of Danish parentage, while all the members of the school board were Danish farmers.

Although Danish parents had gained confidence in the American school system by the turn of the century, ${ }^{24}$ children

21. M. C. Jensen, En Dansk-Amerikansk Praest Erindringer fra 1888-94 (Copenhagen, 1927), 50. Translation: "You see, I was chosen school director and had to hire a teacher for the next term. So I put an announcement in the newspaper, and then he came here to the yard right from the town, he said he was a teacher and was searching for a position. You are the first person to come, I told him, so you can have the position. So he started at the beginning of the term and I believe he gets along all right."

22. By 1897, there were only two Danish schools remaining in Iowa: one in Kimballton and one in Clinton. Both were closed by the turn of the century because of low enrollment. In 1895, 75 children were enrolled in the Danish school in Clinton; ten years later the enrollment had fallen to 29. According to the Manuscript 1900 U.S. Census, there were 172 school-aged DanishAmerican children in Clinton County - 71 in the city of Clinton itself where the school was located. See also Christensen, History of the Danes.

23. Fredsville School, List of Pupils, Directors, and Teachers, 1897-98, Archives of Grand View College, Des Moines.

24. The shortage of ethnic primary schools in the Danish settlements of Iowa is indirect evidence that most Danish-American children attended public schools. In the manuscript U.S. Census for 1900, 1910, and 1920 in Fairfield and Denmark Townships, neither of which had a Danish school, most school-aged children were recorded as being "at school." 
from Danish homes still did not speak much English at the time they started formal instruction. Nonetheless, children apparently made a relatively easy transition between homes where Danish was commonly used and schools where English was the only language spoken. Helena Gaarde of Ringsted recalled, "By the fall 1883 we were told that we would be able to go to school. This news was in one way exciting and in another way frightening. How were we ever going to make out what the American said when all we could understand was the Danish language. We looked forward to meeting other children and I never can remember it being too hard to learn the English. It came so easy when I look back on it." Alice Petersen of Kimballton concurred. "The day I started school," she recalled, "I could speak only the Danish language, probably three-fourths of the class was in the same predicament. Amanda Jensen was our teacher so there was no problem. ${ }^{\prime 25}$

In the first decades of this century, as second-generation Danes entered the labor market, teachers of Danish background began to have a widespread presence in Iowa's rural schools. According to the federal censuses of 1910 and 1920, almost all of the teachers in the rural schools of Denmark and Fairfield Townships were Danish-Americans. ${ }^{26} \mathrm{~A}$ Danish pastor from Copenhagen who visited Iowa in 1905 found many public schools in rural settlements being taught by young Danish-American women, most of whom had been trained at Iowa State Teachers College in Cedar Falls. The pastor considered this a good and natural thing, especially in places where the population was mainly Danish and Danish-American. The pastor did believe, however, that Danish parents should be concerned with giving their children a wider knowledge of Denmark than the few words devoted to their country in the schools' geography textbooks, which-according to the pastor-described Denmark in two lines: "a country which resembles Holland in its products. Copenhagen is its capital and principal city." ${ }^{27}$

25. Ringsted, 1899-1974, 37; Mackintosh, Danskere i Midvesten, 165.

26. Manuscript U.S. Census, 1910 and 1920, Denmark Township and Ringsted town, Emmet County, and Fairfield Township, Grundy County.

27. Johannes Nordentoft, Blandt Danske i Amerika (Copenhagen, 1906), 57-58. 
Guaranteeing a deeper knowledge of Denmark's geography apparently was not the school boards' main motivation for hiring teachers of Danish background. An effort by the Danishdominated school board of Fredsville to incorporate a daily hour of instruction in Danish in the common school in the first years of this century brought internal quandaries and conflict to the community. After a long discussion of whether the public school of Fredsville should promote the reconstitution of former beliefs and the preservation of Danish language among the generations born in America, the idea was voted down in the annual meeting of the congregation. ${ }^{28}$ Apparently few Danes thought Danish schools should interfere with the public school system, where children were supposed to improve their knowledge of English and be trained to perform the duties of American citizenship.

The public schools, in most cases, seem to have helped Danish families move from the exclusive use of Danish to bilingualism, and from bilingualism to the sole use of English. As men adapted to the economic environment, the English language slowly entered Danish homes, but women and small children still communicated mostly in Danish. When children entered the public schools, however, the use of English in the private domain increased. Sometimes families even dropped the use of Danish from daily life entirely in order to improve children's command of English and to avoid mixing both languages, a practice teachers often complained about. ${ }^{29}$

Mainstream Americans' fears about the failure to assimilate immigrants were exacerbated when the United States entered World War I. The anxieties that permeated American society during those years might have accelerated the adoption of English in the Danish settlements. In Iowa, at the height of the patriotic frenzy, the language issue stirred much controversy. When Iowa Governor William Harding visited the Danish settlements in Audubon County on Independence Day, 1918, he told the Danish population of the county that he regretted that the children who grew up in the settlement were not really Ameri-

28. Dannevirke (Cedar Falls), 5 December 1906.

29. Elin and Svend Koch, Verner Jensen, and Ralph Thuesen, interviews by author, Cedar Falls, Iowa, April and September 1995. 
can and even after attending school were "full grown, 100 per cent Danes." Harding proceeded to focus on what America had offered to the Danes. "Now, think of a man who was brought from the filth of Denmark and placed on a farm, for which he paid perhaps $\$ 3$ an acre. Ye gods and fishes, what Iowa has done for him he can never repay! "30 $^{30}$

About six weeks earlier, Harding had issued a proclamation forbidding the use of any language but English in public or private schools, in public conversation, or in religious services. Reactions to the proclamation varied greatly from one congregation to another. The people at Fredsville, where two-thirds of the congregation originated from Slesvig, asked for the proclamation to be modified, observing that they had left their homes in order to preserve their language when the German government prohibited Danish in Slesvig. The Elk Horn congregation, on the other hand, immediately eliminated the Danish Sunday School and converted to using English in worship services. In Kimballton the congregation did not give up their language so easily; two Sundays after Governor Harding issued his so-called Babel Proclamation, the service was conducted in Danish. ${ }^{31}$

Although the language conflict ended with the conclusion of the war, the Danes found that there could be no return to prewar conditions. Throughout the 1920s, English was gradually introduced into Sunday and vacation schools. ${ }^{32}$ In Fredsville, until the early 1920s the vacation school was called Danske Skole because religion, Bible history, reading, and writing were taught in Danish. In 1926, however, the name Danske Skole was omitted and the skole was changed over to a Bible school conducted in English. The change had to be made because in many homes

30. Des Moines Register, 19 July 1918.

31. Kristian Ostegaard Pedersen, Personal Papers, 1855-1931, Archives of the Evangelical Lutheran Church in America, Rosemont, IL, Pa 84; Peter L. Petersen, "Language and Loyalty: Governor Harding and Iowa's Danish-Americans During World War I," Annals of Iowa 42 (1974), 405-17; Jette Mackintosh, "'Little Denmark' on the Prairie: A Study of the Towns Elk Horn and Kimballton in Iowa," Journal of Ethnic History 7 (1988), 46-68.

32. Luther's small catechism was translated into English in 1904. In the 1920s vacation school, which lasted six weeks during the summer, was conducted for three weeks in English and three weeks in Danish. By the following decade, instruction was given only in English. 
Danish was being spoken only rarely and congregations were losing members. ${ }^{33}$

The 1920s were the critical years in the history of Iowa's Danish ethnic communities. On the one hand, Americanization posed threats from outside the community. On the other hand, decreasing Danish immigration and rising numbers in the second and third generations weakened the use of the Danish language. Nevertheless, the gradual abandonment of the language, internal changes, and external pressures did not wholly transform the social boundaries. The institutional and ideological structures of the Danish community in Iowa were still the locus of debates about how this ethnic group would be integrated into American society without betraying its old mores, beliefs, and cultural symbols.

The switch to English in the ethnic institutions-in particular the church-involved controversy at least at the leadership level. Since the early 1890s Danish congregations in the United States had had a history of internal conflict that culminated in the schism of 1894, when the Danish Lutheran church split into two movements: the Inner Mission and the Danish or Grundtvigian church. The disagreement between these two factions had been developing within the Danish church since the early nineteenth century, although in Denmark the two factions coexisted within one church. The Inner Mission was a conservative religious movement that from 1861 had set out to win adherents to its version of personal faith that relied on a literal interpretation of the Bible and pietistic religious practice. Grundtvigians, inspired by the teachings of the Danish nationalist bishop N. S. F. Grundtvig, had formulated a different interpretation of Christianity that expressed a concern that people be awakened culturally as well as spiritually. ${ }^{34}$

In the United States the confrontation between Inner Mission and Grundtvigian adherents also revolved around their diver-

33. Fredsville Lutheran Church, 1871-1971 (n.p., n.d.); Dannevirke, 28 October and 3 November 1926.

34. Henrik Bredmose Simonsen, "Differences in Cultural Assimilation in Similar Danish Immigrant Communities: The Case of Grundtvigians and Inner Mission Supporters," in Birgit Flemming Larsen et al., On Distant Shores (Aalborg, 1993), 287-98. 
gent positions on the assimilation of Danish immigrants in foreign countries. The task for the Grundtvigians was to bring about the spiritual and cultural awakening of the Danes in America. The more orthodox proclaimed that it was possible to leave one's country but never one's folk (or national consciousness). Therefore, the Grundtvigians emphasized the importance of preserving the Danish cultural heritage among immigrants and their children. On the other hand, the importance the Inner Mission movement placed on reaching the unchurched not only among the Danish immigrants but others as well tended to separate religious and cultural work, making preservationist efforts less central. ${ }^{35}$

Pastors H. C. Strandskov, K. Ostergaard, and F. L. Grundtvig (Bishop Grundtvig's son) were among the most conspicuous supporters of the Grundtvigian movement in Iowa. From the early years of Danish settlement in Iowa, those ministers advocated the preservation of the Danish language among the children of Danish immigrants born in America who, according to Strandskov, were "bound with the holy ties of the blood to the Danish people and tongue." In what may be called the battle about the children, the public schools came to loom prominently. The most bitter opponent of the common schools was Pastor F. L. Grundtvig, who, from the pulpit of his church in Clinton, stated that "the public school is the most arrant enemy of the Danish people and the Danish church." ${ }^{36}$

Grundtvigian opinions regarding public versus ethnic education, continuity of the Danish ethnic heritage, and preservation of the language were popular among certain groups in the late nineteenth century. At that time the first generation still outnumbered the second generation, some congregations still had Danish schools, and the use of Danish was still widespread in the community. By the 1920s much had changed. Although the Grundtvigian pastors had worked hard to defend their convic-

35. On the conflict between Grundtvigians and Inner Mission adherents within the Danish church in the United States, see Henrik Bredmose Simonsen, Kampen om Danskheden: Tro of Nationalitet $i$ de danske kirkesamfund i America (Aarhus, 1990); Thorvald Hansen, Church Divided: Lutheranism among the Danish Immigrants (Des Moines, 1992); and Nyholm, Americanization.

36. Nyholm, Americanization, 233. 
tions, most ethnic schools had been closed, the overwhelming majority of Danish-American children were attending public schools, and the second and third generations had adopted the use of English. Nonetheless, the perpetuation of the Danish language was still an unresolved problem at least at the level of the church leadership. Danish newspapers devoted much space to the debate of this problem in articles and editorials written by Grundtvigian pastors and lay people. The argument over retaining the Danish language was carried on almost up to the last issue of the Dannevirke (the Grundtvigians' press organ) in 1951, long after the church had switched to English and almost everyone else had accepted Americanization as an accomplished fact. ${ }^{37}$

The Inner Mission faction was much less concerned with perpetuating Danish customs and language. The following statement from 1916 reveals the pragmatism of the pietistic group when dealing with the issue of language preservation:

What language shall we use at our young people's meetings? First of all let us remember that the language is not our task or our goal, it is only a tool or means with which to do our work. Therefore, it is important to use that language which best serves in the various places. Where there is a young people's society which consists chiefly of Danish-born youth, we will use the Danish language, at least in part as also among the older members of the congregation. ... On the other hand, where the young people's society consists of American-born youth ... there it is completely senseless to force the Danish language upon them and thereby hinder our work. ${ }^{38}$

The debates over the Danes' integration into American society seem to have been confined to the ethnic and religious leadership. Most Danish immigrants did not join the church, ${ }^{39}$ and few of them were aware of the controversies about either the interpretation of the Bible, the integration of the Danes into the host society, or the importance of preserving the language and culture of the Old World. Many Danish-Americans now living in Iowa recall their Danish parents or grandparents "celebrating" the ideals of integration and unity represented in the

37. Marion Marzolf, The Danish-Language Press in America (New York, 1979), 116.

38. Nyholm, Americanization, 244.

39. O. C. Olsen, Early Days in Our Congregation (Chicago, 1940), 33. 
motto "e pluribus Unum" and sharing the conviction that in America success and rewards were reserved for those who mastered the language and were familiar with the cultural codes of the New World. Of course, one might be skeptical of images that portray Danish farmers happily accepting their integration into American society since their recollections are permeated by civic rhetoric and the symbolic representations common to the discourse of Americanization transmitted by public schools. Rapid assimilation and the dissolution of ethnic boundaries were part of the goals of the Americanization movement based on a symbolic delegitimation of ethnic identities. The discourse of the movement entered the public school system in its effort to secure cultural and ideological hegemony through the configuration of the symbolic order and the redefinition of American civic culture. ${ }^{40}$ Nonetheless, the public schools' role in promoting the use of English and the abandonment of Danish among immigrants in Iowa is unmistakable.

EDUCATION played a very different cultural role for Danish immigrants in Argentina. When the first group of Danes settled in Tandil in the summer of 1860 , two public schools were operating in the small frontier village. The schools had been created in 1853, when a handful of neighbors formed a municipal commission presided over by the Danish pioneer Hans Fugl. Despite the commission's efforts, education apparently was not a main concern of the neighbors in the frontier society. Even the authorities of the provincial state who supposedly promoted education proved to be oblivious to the frontier schools' need for financial support. The scarcity of economic resources made the schools of Tandil extremely primitive. Due to low salaries, teachers-a scarce resource in rural Argentina-often resigned, making instruction discontinuous. ${ }^{41}$

40. Michael Olneck, "Americanization and Education of Immigrants, 1900-1925: An Analysis of Symbolic Action," American Journal of Education 97 (1989), 398423.

41. Dorothea Fulg, Diary, 1860-1875, Archivo Histórico Municipal, Tandil; Hans Fulg, Memorias de Juan Fugl: Vida de un pionero danés durante 30 años en Tandil, 1844-1875 (Tandil, 1989); Fontana Roberto, Tandil en la Historia (Tandil, 1956). 
The creation of schools in the Argentine countryside was slow and erratic. Even in turn-of-the-century rural areas of the province of Buenos Aires, schools were scarce and unevenly distributed. It was not unusual to find entire townships without a single common school. In contrast to Iowa, where schools dotted the countryside and were within easy walking distance from almost every dwelling, children in the pampa frequently had to ride on horseback eight to ten miles in order to reach the closest school.

Despite the priority given to public education by the Argentine political elite, it would take decades to solve the problem of school scarcity. Domingo F. Sarmiento, one of the nation's founders and president of Argentina from 1868 to 1874, visited the United States in 1847. While there, he met Horace and Mary Mann, who introduced him to the American public school system. Later, Sarmiento would attempt to improve the quality of education in Argentina by importing American teachers. ${ }^{42}$ Sarmiento was fascinated by the freedom of local American communities to control their schools with little state interference. Parents' control over the education of their children through participation in township school boards that hired teachers and managed school funds epitomized for Sarmiento the federal and democratic practices prevailing in the U.S. public school system. ${ }^{43}$

In Sarmiento's travel commentaries as well as in passages of his book, De la Educación Popular, he highlighted the contrasts between the United States and Argentina. He idealized the United States while applying to Argentina "the dimensions of a critical realism. ${ }^{\prime \prime 4}$ Sarmiento dreamed of a country of small owner-operated farms, with schools controlled by the community and with neighborhood school boards elected by district voters. He was never to see the Argentina of his dreams. The interference of the state- both federal and provincial—in public

42. In the late 1860s Mary Mann helped Sarmiento recruit American teachers for Argentine schools. Natalio Botana, Domingo Faustino Sarmiento, Colección Los Nombres del Poder (Buenos Aires, 1996), 40-41.

43. Domingo F. Sarmiento, De la Educación Popular, in Obras Completas de Domingo Faustino Sarmiento, vol. 11 (Buenos Aires, 1950).

44. W. H. Katra, "Rereading Viajes: Race, Identity, and National Destiny," in Tulio Halperín Donghi et al., eds., Sarmiento, Author of a Nation (Berkeley, CA, 1997), 73-100. 
education left little room for popular initiative in school affairs. In 1884 the federal government promulgated a law that gave the government a powerful tool to control the public school system. The Consejo Nacional de Educación, whose members were appointed by the president with the agreement of the senate, supervised the nomination of all of the members of the local school district councils. In the provinces, the governments adopted a similar organization, creating Consejos Provinciales de Educación to control public and private schools. ${ }^{45}$

The laws of education the federal and provincial governments passed in the 1880 s included nothing comparable to the American neighborhood school boards composed of parents. In spite of the impulse those laws gave to education, it took decades for the national and provincial governments to solve the problems of Argentina's public school system. The shortage of schools in the countryside was still an unsolved problem in the late 1920s.

By the turn of the century in the partidos of Tandil, Necochea, and Tres Arroyos, most schools were located in the primary towns, where only a third of the entire population resided. In 1906, in the partido of Tres Arroyos, there were 23 schools, 16 of which were located in the town, with the other 7 scattered over a wide rural area of almost 5,900 square kilometers. That same year, about 4,500 children between 6 and 14 years of age lived in the partido, but only 20 percent of them attended school. In ejidos such as Lumb, with one of the largest concentrations of Danish immigrants in the partido of Necochea, there were no schools when the first 30 Danish families arrived in 1914 from Tandil and Tres Arroyos to settle the area. The first public school in Lumb did not open until 1922 . $^{46}$

In 1901, agents in Copenhagen distributed a guide for Scandinavian emigrants to Argentina when they purchased their tickets. The guide pointed out that one of the disadvantages of

45. Juan Carlos Tedesco, Educación y Sociedad en la Argentina (1880-1945) (Buenos Aires, 1970); Adriana Puiggrós, ed., Escuela, Democracia y Orden (19161943): Historia de La Educación Argentina, vol. 3 (Buenos Aires, 1992).

46. Roberto Gorraiz, Historia de Tres Arroyos (Tres Arroyos, 1935); Carlos Angeleri, ed., Guía de Tres Arroyos (Tres Arroyos, 1928); Archivo del Consejo Provincial de Educación de Necochea, Registro de Escuelas del Partido, 1900-1925. 
Argentina as a destination was the scarcity of schools in rural areas where the main Danish settlements were located. However, the guide mentions the huslaer (home teacher), a solution to the problem found by the Danish farmers of the province of Buenos Aires. "Generally the Danish farmers use a huslaer for giving their children some elementary instruction. Normally huslaere are poorly qualified. . . . They often work both as teachers and farmhands on rural estates and after having finished their daily tasks, instruct the farmers' children."${ }^{1{ }^{47}}$ Hiring private teachers to educate children living in the rural world of the province of Buenos Aires was a widespread practice regardless of the families' ethnic origin. The local newspapers of Tres Arroyos and Necochea often published announcements from local farmers seeking men or women able to perform as both rural laborers or servants and as home teachers. ${ }^{4}$

In turn-of-the-century Argentina, the lack of organization in the school system, the low level of education, the scarcity of schools in the rural world, and illiteracy seem to have been endemic problems. The increasing centralization of state control of the public school system proved ineffective in vast rural areas where schools and teachers were a rarity. In these unfavorable circumstances, the Danish Lutheran churches of Tandil, Necochea, Lumb, and Tres Arroyos took responsibility for organizing ethnic schools to secure their children's education.

The church played a central role in the history of the Danes in Argentina and in their adjustment to the new society. This is not to say that the church was a pervasive influence in everyone's life-or even that everyone in a given settlement was a church member. Yet the churches, individually and collectively, performed social roles that were crucial to the life of the community.

The first Danish church in Argentina was built in Tandil in 1877. As Danish settlements in the province of Buenos Aires continued to expand southward, new congregations were founded-one in Tres Arroyos in 1901 followed by one in

47. Consulado Danés de Buenos Aires, Vejleder for Danske Udvandrere til Argentina (Buenos Aires, 1901).

48. La Voz del Pueblo (Tres Arroyos), 1900-1920; Diario del Pueblo (Tres Arroyos), 1919-1923; Ecos Diarios (Necochea), 1925-1930. 


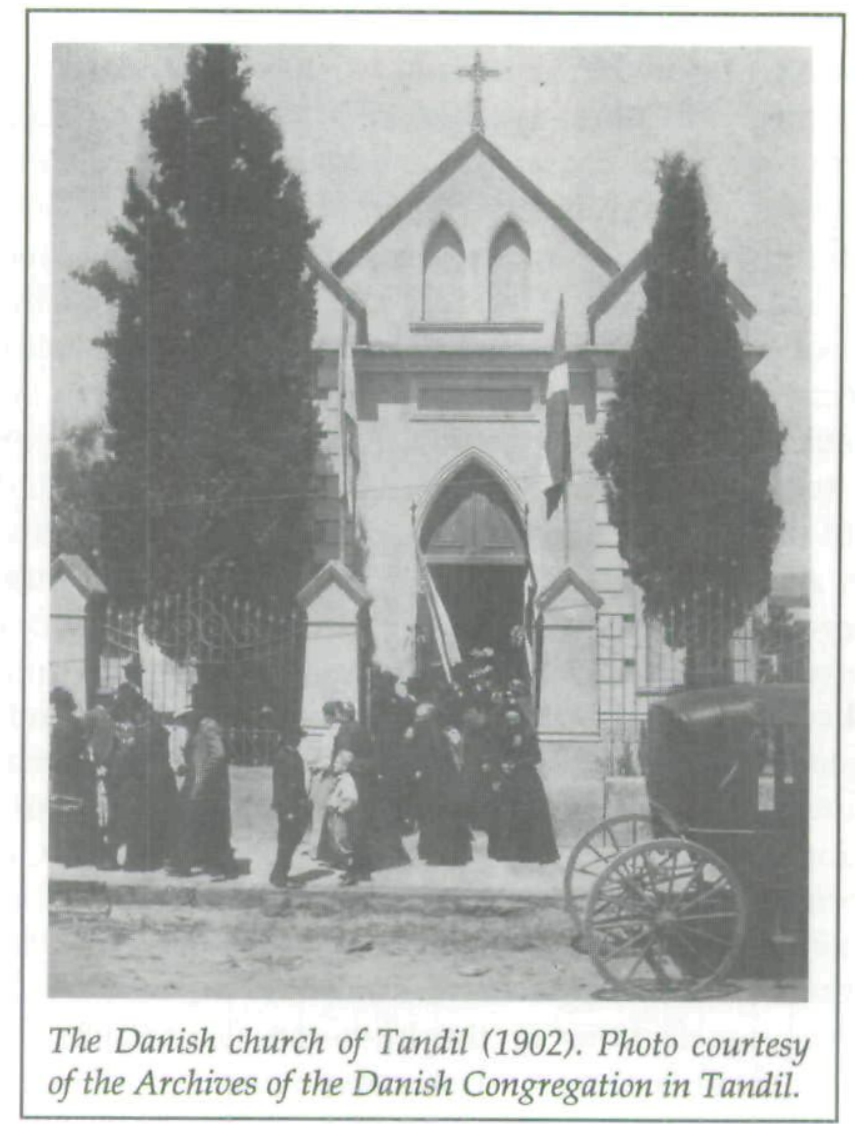

Necochea in 1918, and a forsamlinghus (which performed both religious and educational activities) in Lumb in 1921. The church sponsored educational, social, and cultural activities as well as providing recreation and regulating the integration of the immigrants and their descendants into Argentine society. ${ }^{49}$

In the early 1870 s Danes from Tandil—by that time the sole Danish settlement in the province-informally began instruct-

49. By 1895, 65 percent of Danes settled in southern Buenos Aires province were affiliated with the Danish Lutheran church of Tandil. By 1914, that number had dropped to 51 percent. By that time, however, there was another Danish Lutheran church in the community, the one founded in Tres Arroyos in 1901. República Argentina, Segundo y Tercer Censo Nacional de Población (Buenos Aires, 1895 and 1914); membership records of Tandil's Danske Kirke and Tres Arroyos Danske Kirke (1895 and 1914). 
ing a handful of Danish children first in private homes and by 1876 in the church, where the newly arrived pastor and his wife had improvised an elementary school. Instruction was in Danish, although the congregation soon hired a local teacher to instruct students in Spanish.

By the end of the 1880s, the Tandil congregation had received its second minister, Niels Dael. He had graduated from the Folk High School of Askov, one of the Grundtvigian pedagogical centers of Jutland. Dael was soon followed by a group of families from the parish he had served in the region of Mors in northern Jutland, where Grundtvig's ideas had become popular, and by a couple of teachers he had met in Askov. During the decade he spent in Argentina, Dael created a model concerned not only with preaching and theological work but, above all, with inculcating a strong Danish patriotism in the Danish-Argentine children. The pastor and his coworkers seized upon this mission, seeking to foster an education that would not only instruct the immigrant youth but also contribute to the preservation of the Danish language and cultural traits in Argentina. The Grundtvigian principles of the pastor and the teachers shaped the Danish immigrants' adaptation to the new society, although none of the congregations in Argentina would fully affiliate with either of the religious factions of the Lutheran Danish church that brought internal conflict and schism to the Danish-American congregations. ${ }^{50}$

During the second half of the 1880s, the school in Tandil became the church's primary cause, and the church's leaders made determined efforts to preserve the language and traditions of a country that many from the second and third generations would never know directly. From that time forward the church not only actively pushed for the construction of a school-which was

50. Minutes of church meetings between 1886 and 1910, and copies of letters sent by pastor Niels Dael between 1889 and 1897 to his friend in Mors, Johannes Bennike (one of the teachers Dael attracted from Denmark to Tandil), Archives of the Danish congregation of Tandil; Aarsskrift for Dansk Skoleforening i Argentina (1909), 3-36; Oluf Johansen, Johannes og Katrine: En sandfaerdig fortaelling fra Danmark og Argentina (Eldorado, 1944); Erik Dybdal Möller, National og konfessionel egenart paa latinamerikanske praemisser: Forholdet mellen de Danske menigheder og andre Lutherske menigheder of kiker $i$ den Katolske kultursamenhaeng $i$ Argentina (Aarhus, 1990). 
finally opened in 1886 - but also encouraged discussion of what type of education should be provided. After much argument regarding the traits of education in the Danish schools, a model was adopted by the turn of the century. The principal traits of the model had been defined by Pastor Niels Dael-the first principal of the Tandil Danish school-and the group of Grundtvigians who had followed him from Askov and Mors. The instruction of the children revolved around the transmission of the Danish language, symbols, national iconography, and religion. ${ }^{51}$ Since the majority of the students had been born in Argentina, however, they also needed to be familiar with the culture, traditions, and language of the country adopted by their parents. Finding a balance between these antagonistic value systems was a constant preoccupation and topic of discussion within the congregations.

As the 1890s came to a close, the Argentine Danes tacitly adopted the Grundtvigian principles and began to erect a figurative wall around the community. Not unlike Iowa Danes, most Danish immigrants in Argentina were aware only superficially —or not at all —of contemporary debates within the Danish church and the nationalist ideals of the Grundtvigian movement. ${ }^{52}$ The reality of their situation, however, caused these immigrants, some with conscious intent and others because they were caught up in the forces of the times and in the necessities imposed by the host society (the lack of public schools in the rural areas, for example), to gravitate toward Grundtvigian ideas and attempt to create a "Little Denmark" on the other side of the world. This constituted a longer but, from their standpoint, less traumatic road toward adaptation to Argentine society.

51. Program of study for the Danish school in Tandil between 1897 and 1920, Archives of the Danish Congregation of Tandil; Lars Baekhöj, "Lidt om den Danske Skole i Tandil," Aarsskrift for Dansk Skoleforening for Tandil (1908), 5-16.

52. In the period 1878-1930, references to the Grundtvigian or Inner Mission movements are found only rarely in the minutes of the church meetings in Tandil, Tres Arroyos, and Necochea. One of the few occasions when the minutes refer to the two wings of the Danish church is during a conflict between the congregation and the pastor of the church of Tandil that lasted from October 1907 to May 1908 (see below). 


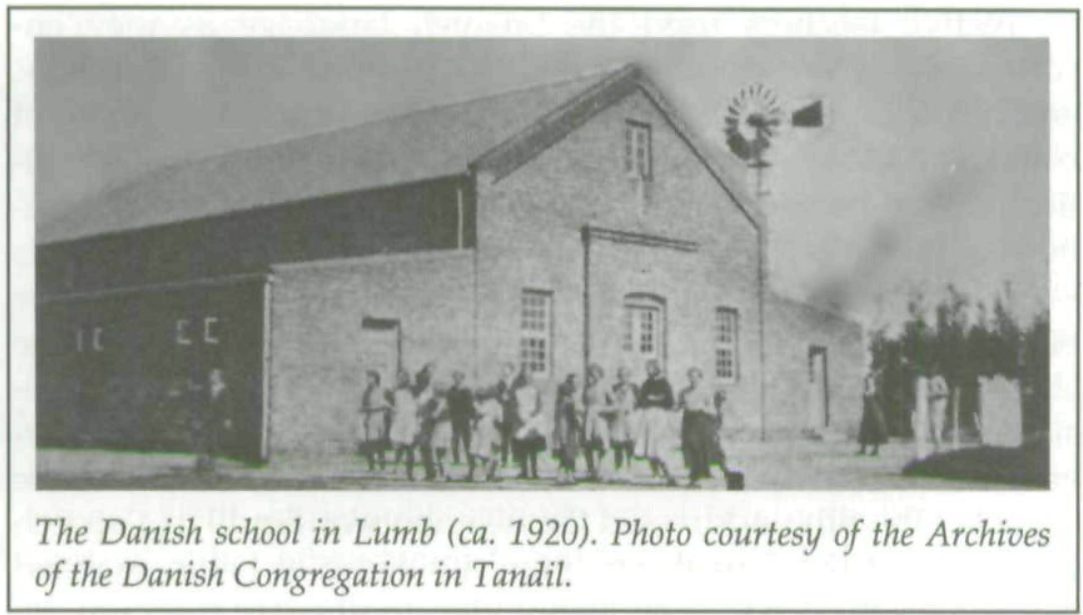

Educating children whose parents were both Lutheran and Danish in a Catholic and Spanish-speaking country required a curriculum that would include Argentine subjects. To fulfill the state requirements for ethnic schools, Argentine teachers were also needed. ${ }^{53}$ Because one of the purposes of the church was to preserve the Danish language, the school's curriculum followed the one used by most elementary schools in Denmark, and teachers were hired mostly from the old country. During the school day, the children spent many hours improving their skills in the language they spoke to their parents daily. From Monday through Friday, the children spent 70 percent of their time at school studying the history, geography, religion, and language of Denmark. In the afternoon those same students heard another language, became acquainted with another geography, familiarized themselves with a new culture, and learned to respect the great men who had ruled their new homeland many years after the reigns of the Danish kings Valdemar Sejr or Christian IV. ${ }^{54}$

53. After the turn of the century the Consejo Nacional de Educación made the use of Spanish compulsory. Lilia Ana Bertoni, "Nacionalidad o Cosmopolitismo: La cuestión de las escuelas de las colectividades extranjeras a fines del siglo XIX," Anuario IEHS 11 (1999), 179-99.

54. Minutes of church meetings between 1886 and 1895, List of teachers between 1890 and 1925, and Program of study and schedule hours for the Danish schools in Tandil (1897-1910) and Tres Arroyos (1901-1919), Archives of the Danish congregations of Tandil and Tres Arroyos. 
Native teachers used the Spanish language as they encouraged students to identify with Argentine values, symbols, and history, gradually helping the children formulate a sense of belonging to the adopted country. The nature of this dual identification can be seen in the school's participation in the celebrations of the centenary of the town of Tandil in 1923. The students -displaying the flags of their two countries-marched in honor of General Martín Rodríguez (the founder of Tandil) while the church presented the town with two Danish porcelain vases designed in Copenhagen especially for the occasion. Pastor Thorvald Andresen, the minister of the church and principal of the school at the time, addressed the neighbors of Tandil in a speech that stressed the Danish community's sense of belonging and close connection to the history and development of the town.

Seventy years ago, when this town was in its beginnings, the first Danish farmer, Hans Fugl, arrived. Thousands of compatriots attracted by the liberty of this land followed him.... we are from a country of peasants, farmland, and woods and this has been our bequest to this nation, we were the first to till the land and plant trees in this region. ... After Buenos Aires, Tandil is the most wellknown South-American city in Denmark. ... Names such as Hans Fugl, Manuel Eigler, Poul Christiansen or the brothers Mathiasen, Manuel Vogeluis, Adolf Petersen ... will be recorded in the annals of this town. ${ }^{55}$

Pastor Andresen's speech reflected more his own convictions and willingness to participate in Argentine life and culture than the convictions of the group as a whole. In the early years of the century Andresen's congregation experienced a great deal of conflict because of his attempts to preach in Spanish in the Danish Lutheran church and to attract new parishioners regardless of their ethnic origin or previous religious affiliation. After much debate and internal upheaval, the majority of the congregation completely rejected Andresen's proposal to open the church to outsiders. ${ }^{56}$

55. Aarsskrift for Dansk Skoleforening i Argentina (1923), 39; El Eco de Tandil, 16 April 1923.

56. Minutes of Danish Church of Tandil, October 1907-May 1908; Tandils' Tidende, 23 November and 3 December 1907 and 2 February and 20 May 1908. 
The community still had a long way to go to fully adjust to Argentine society. Their interaction with the native society was confined largely to relationships of a secondary sort, above all, to contacts based on work and economic relations in the marketplace and occasionally to public celebrations. Most of the primary social interactions that held the community together, however, still took place almost exclusively within the ethnic and religious boundaries of the group.

The immigrants' children, however, adapted to the new reality in a different way. The first generation, confronted with the intensity of a reality so different from their own, repeatedly voiced their fear of being overwhelmed by the host society and thus losing their Danish identity. Retaining the Danish language, religion, customs, and beliefs in the midst of the Argentine pampa required the commitment of the second generation. Many times internal quandaries regarding the reproduction and reconstitution of former beliefs perplexed the members of the community. For example, Pedro Delmar, a Danish writer who was concerned about the pace of the community's integration into Argentine society, commented,

The question which almost always naturally arises ... is whether we should remain Danish or surrender and let time turn us into Argentines and whether our children born in this country should receive a Danish or Argentine education. ... The colony will become Argentine, that for certain, but we should try to ensure that this process occurs as slowly as possible! ... Because of the migration of their parents, the second generation has lost their ability to experience the Danish culture and spirit but neither have they been able to establish a clear identification with the national culture and spirit of Argentina.... [The second generation] is neither completely Danish nor completely Argentine. ${ }^{57}$

The school was entrusted with the herculean task of reconstituting the Danish spirit that those generations born in Argentina were not able to experience directly. By creating an imaginary Danishness, education would help to delay the community's complete absorption by Argentine society. No one,

57. Pedro Delmar, "Andet Slaegtled," Aarsskrift for Dansk Skoleforening i Argentina (1915), 7-8. 
however, could deny that the children were at least partly Argentine. Finding a balance between the Danish legacy and the new value system, which had a strong hold on the youth (although this was not overtly acknowledged), was the central preoccupation of the church and the Danish school.

A variety of arguments maintained that education should be developed within the boundaries of the community. Most of the arguments, however, revolved around the quality of the pedagogical methods and materials brought from Denmark. Instruction that followed the model of Denmark's elementary schools was considered most appropriate for immigrants' children, who, although born in Argentina, were recognized as different from both native and other children of foreign parentage. ${ }^{58}$

Many Danes were strongly race conscious, despised "dark Argentines," and considered Argentina an inferior society. Some of those who argued in favor of educating Danish children within the boundaries of the community claimed that because Denmark was a superior nation the Danish educational system had to be transplanted in its entirety to Argentina..$^{59}$ Others, such as Lars Baekhöj, a Grundtvigian teacher and graduate of Askov, advocated a more moderate position. He was principally concerned with determining the proper balance between Lutheran and Danish values, on the one hand, and Catholic and Argentine ones, on the other, in the education of children. According to Baekhöj, it was somehow natural to transmit the spirit of the distant homeland of their parents to the children by teaching a history that stretched back to Vikings and monarchs, or by requiring students to recite the following verses from Hans Christian Andersen at every school celebration: "I Danmark er jeg födt, der har jeg hjemme, der har jeg Rod, derfra min Verden gaar" ["I was born in Denmark, my home and my roots are there, from there my world makes sense"]. Nonetheless, children's failure to identify with Denmark as their parents and teachers did caused Baekhöj to wonder whether trying to transmit all of these values-which the children were not

58. Juan Andersen, "Skolen i Tandil," Aarsskrift for Dansk Skoleforening i Argentina (1919), 10.

59. J. Sommer, "Til foraeldrene af Skolepligtige Börn," Aarsskfrit for Dansk Skoleforening i Argentina (1919), 22. 
even capable of completely absorbing-constituted a futile enterprise: "the songs as well as the History do not have an authentic base on which to establish themselves and thus love for the homeland lacks a foundation. ${ }^{\prime 60}$

The children might have often experienced a sense of divided loyalty. They had another homeland, another language, and another history in which José de San Martín, Domingo F. Sarmiento, and the rallying cry of the Argentine anthem, "Oid mortales el grito sagrado," were the protagonists. Balancing the faint shadow of Denmark with the powerful presence of Argentine reality was a problem that preoccupied many immigrants and did not find resolution.

The school reinforced a process that undoubtedly would have taken place sooner or later: the emergence of a new identity that was neither completely Danish nor Argentine. This hybrid identity came about through the combination of Danish language, symbols, and religion transmitted by the first generation and the daily experiences of the immigrants' children in the Catholic and Spanish-speaking Argentine society.

The main preoccupation of the school and congregational leaders was to foster within the children an affinity for a system of values that supported the Danish side of their identity, persuading them to find meaning in the verses, "I was born in Denmark, my home and my roots are there." At some level this song meant something to all of the Danish immigrants and to a great extent captured the experience of maintaining a Danish education in the midst of the Argentina pampa. However, its significance must have resonated much more strongly for the adults than for the children. Nonetheless, the generation born in Argentina was entrusted with the realization of the preservationist goals of the school and the church. Most of these trustees, however, would never see the pale green of the first spring Danish beech trees or the intense blue of the Kattegat under the radiant sky of Skagen.

THROUGHOUT the second half of the nineteenth century and the first decades of the twentieth century, the ethnic traditions

60. Lars Baekhöj, Danske i Argentina (Copenhagen, 1948), 40. 
of the Danish settlements in Iowa and Buenos Aires informed patterns of community life. At the same time, these localized traditions competed with larger national and ethnic structures of which these communities were increasingly a part. Rural Danish settlements on the prairies and the pampa were caught between the interaction of forces of an ethnic culture and the assimilationist pressures of the outside world. But the response of both communities was different.

In the ethnically integrated rural world of the pampa, Danish immigrants were able to foster a separate identity and maintain, well into the twentieth century, clearly demarcated cultural and religious boundaries that separated them from the local society. In Iowa, the ethnic boundaries of the Danish community began to fade away earlier, and the adaptation to American society was seemingly faster. The transition from the first to the second generation and the latter's pervasive adoption of the English language seems to have been one of the critical facts in the process of amalgamating the Danish immigrants into the pluralistic whole of American society.

In addition to the differences in religion and education emphasized here, a number of other factors help to explain the divergent ways Danish immigrants adapted to Argentine and American society. The different cultural contexts of the prairies and the pampa played a role in the patterns of adjustment of both groups. In Argentina, Danes were a cultural and religious minority, while in the United States they were not. In the pampa, Danes lived in a dominant Latin and Catholic context, where most of the population had Italian and Spanish origins. In Argentina, the contrast between the ethnic culture and the host society led Danes to consciously attempt to hinder the intrusions of the outside world. In contrast, Iowa's cultural and religious environment might have seemed more familiar to the Danish immigrants arriving in the nineteenth-century Midwest. Settled in Danish clusters and surrounded by other Scandinavians and northern European immigrants, and by a Protestant majority, Danes in Iowa might have felt that their culture and religious beliefs were not very seriously threatened.

The pace of Danish migration to Argentina and the United States and the involvement of the latter in World War I also help 
to explain differences in the ways Danes adapted to each setting. By the beginning of the war, the flow of Danish immigrants to the United States had started to decrease, while in Argentina the settlements in the province of Buenos Aires continued to receive immigrants from Denmark until the economic crisis of 1930. Moreover, the American quota laws of the 1920s contributed to an increase in the flow of Danish immigrants to the rural world of the pampa. These new arrivals brought freshness to an ethnic culture that was continually being reconstituted. This was not the case in the rural Danish settlements in Iowa. The decrease in the number of Danish immigrants and the exacerbation, during World War I, of the debate over how ethnic groups ought to be integrated into American society seemingly strengthened the Danes' allegiances to the American nation and accelerated the adoption of English language in the institutional life of the community. While in the 1920s Danes in Argentina still pledged allegiance to their cultural and religious past, reinforcing the Danish side of their identity, in the United States the ethnic boundaries of the community were slowly fading away.

However, the use of the English language and the intrusion of the outside world in the ethnic rural communities were not new phenomena. English had begun to enter Danish homes with children's public school attendance. Despite the importance of the factors mentioned in the preceding paragraphs, the roles of the church and the school (or religion and education) are the critical factors in explaining the divergent ethnic trajectories of Danes on the prairies and the pampa.

In The Transplanted, historian John Bodnar asserts that "no institution in immigrant America has exhibited more discord and division than the Church. ${ }^{\prime \prime 1}$ The Danish church was no exception. The quandaries of a church transplanted to a sectarian landscape provoked a conflict between the Inner Mission and the Grundtvigian wings of Danish Lutheranism. In 1894 the Danish church split into two denominations. Nothing similar to the conflict that erupted within the Danish community in the United States occurred in the Danish settlements of Argentina.

61. John Bodnar, The Transplanted: A History of Immigrants in Urban America (Bloomington, IN, 1985), 166. 
In both settlements the church served as a community organization. Nonetheless, the temporal battles and the theological debates that entered the church in the United States seemingly diminished the church's centrality in the community and particularly in the ethnic institutional structure. In Argentina (a nonsectarian landscape, where Danes were a religious minority), the church was a centripetal force that supported the establishment of other institutions that could contribute to the reconstitution of former beliefs and ethnic culture. The Danish school was the institution most clearly charged with this responsibility.

By creating Danish schools, the congregations of the pampa not only secured continuity with their cultural past, but also solved the problem of educating Danish-Argentine children in a rural world where schools and teachers were rare. The Argentine state had proved unable to secure an educational system that could fulfill the needs of both urban and rural residents. Danish schools and Danish home teachers were the solution found by Danish farmers of the pampa for the deficiencies of the public educational system. They created and controlled schools where second- and third-generation Danish-Argentine children were instructed mostly in Danish by Danish teachers who followed the educational programs of primary schools in Denmark.

While in the rural world of the pampa the lack of public schools was an unsolved problem well into the first decades of the twentieth century, on the prairies of nineteenth-century Iowa public schools dotted the countryside. In the first decades of Danish settlement, ethnic leaders promoted parochial schools for their descendants, but soon most Danish parents sent their children to public schools, which became one of the most instrumental institutions in bringing about the diffusion of American practices and the English language among the immigrant community. While youths used English at school and brought the language of America to their Danish homes, Danish farmers participated in American public life by controlling their local school boards. Eventually, Danish-Americans on Iowa's prairies adopted English exclusively, while Danes on the Argentine pampa retained their knowledge of the Danish language and culture. 
Copyright of Annals of Iowa is the property of State of Iowa, by \& through the State Historical Society of Iowa and its content may not be copied or emailed to multiple sites or posted to a listserv without the copyright holder's express written permission. However, users may print, download, or email articles for individual use. 